\title{
A Hydroalcoholic Extract from the Leaves of Nerium oleander Inhibits Glycolysis and Induces Selective Killing of Lung Cancer Cells
}

\author{
Authors \\ José Manuel Calderón-Montaño ${ }^{1}$, Estefanía Burgos-Morón ${ }^{1}$, Manuel Luis Orta ${ }^{2}$, Santiago Mateos ${ }^{2}$, \\ Miguel López-Lázaro ${ }^{1}$ \\ Affiliations \\ ${ }^{1}$ Department of Pharmacology, Faculty of Pharmacy, University of Seville, Seville, Spain \\ ${ }^{2}$ Department of Cell Biology, Faculty of Biology, University of Seville, Seville, Spain
}

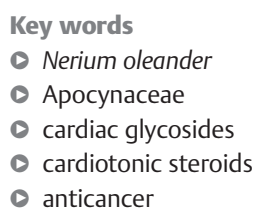

received April 25, 2013

revised May 24, 2013

accepted May 31, 2013

\section{Bibliography}

DOI http://dx.doi.org/

$10.1055 / \mathrm{s}-0032-1328715$

Published online July 3, 2013

Planta Med 2013; 79:

1017-1023 @ Georg Thieme

Verlag KG Stuttgart - New York . ISSN 0032-0943

\section{Correspondence}

Dr. M. López-Lázaro, Associate Professor

Department of Pharmacology

Faculty of Pharmacy

C/Profesor Garcia Gonzalez 2

41012 Sevilla

Spain

Phone: + 34954556348

Fax: + 34954556074

mlopezlazaro@us.es

\section{Abstract \\ $\nabla$}

Recent evidence suggests that cardiac glycosides might be used for the treatment of cancer. The ornamental shrub Nerium oleander has been used in traditional medicine for treating several disorders including cancer, and extracts from the leaves of this plant have already entered phase I clinical trials. In this communication, we have prepared a hydroalcoholic extract from the leaves of Nerium and have assessed its cytotoxic activity in A549 lung cancer cells vs. MRC5 nonmalignant lung fibroblasts. The results showed that the cytotoxicity of the Nerium oleander extract against the cancer cell line was significantly higher than that against the nonmalignant cell line, with a potency and selectivity similar to those of the anticancer drug cisplatin. Pretreatment of A549 cells with the antioxidants $N$-acetylcysteine and catalase slightly prevented the cytotoxicity of the extract, therefore suggesting that the formation of reactive oxygen species participates in its cytotoxic activity but does not play a major role. Nerium oleander extract-induced cytotoxicity and DNA damage (gamma-H2AX focus formation) were slightly higher in cells lacking BRCA2 (deficient in homologous recombination repair) than in parental cells; this indicates that the induction of DNA damage may also play a role in the cytotoxicity of the extract. Nerium oleander extract induced a marked inhibition of glycolysis (glucose oleander (containing $4.75 \pm 0.32 \%$ of cardenolides)

consumption and lactate production) in A549 cells, comparable to that of the glycolysis inhibitor dichloroacetate (currently in clinical development for cancer therapy). Because platinum compounds are widely used in the treatment of lung cancer, we tested the cytotoxicity of several combinations of cisplatin with the extract and found a moderate synergism when Nerium oleander extract was administered after cisplatin but a moderate antagonism when it was added before cisplatin. Our results suggest that extracts from $\mathrm{Ne}$ rium oleander might induce anticancer effects in patients with lung cancer and support their possible advancement into phase II clinical trials for the treatment of this type of cancer.

Abbreviations
$\nabla$ $\begin{array}{ll} \\ \text { BRCA2: } & \text { breast cancer type } 2 \\ \text { CI: } & \text { combination index } \\ \text { DAPI: } & \begin{array}{l}4^{\prime}, 6 \text {-diamidino-2-phenylindole } \\ \text { dihydrochloride }\end{array} \\ \text { DCA: } & \text { dichloroacetate } \\ \text { DSB: } & \text { double strand break } \\ \text { HR: } & \text { homologous recombination } \\ \text { NAC: } & \text { N-acetylcysteine } \\ \text { NOE: } & \text { Nerium oleander extract } \\ \text { PFK: } & \text { phosphofructokinase } \\ \text { SGLTS: } & \text { sodium glucose transporters } \\ \text { ROS: } & \text { reactive oxygen species } \\ \text { SEM: } & \text { standard error of the means }\end{array}$

\section{Introduction} $\nabla$

Cardiac glycosides are a group of natural products that share a steroid-like structure with an unsaturated lactone ring and the ability to inhibit the $\mathrm{Na}^{+} / \mathrm{K}^{+}$-ATPase pump. The lactone moiety at position 17 defines the two classes of cardiac glycoside: cardenolides (with the lactone 2-fu- 
bain, bufalin, marinobufagenin, and telecinobufagin. Some cardiac glycosides are used in cardiology for the treatment of cardiac congestion and some types of cardiac arrhythmias. The mechanism by which these drugs affect cardiac contractility is known to be mediated by a highly specific inhibition of $\mathrm{Na}^{+} / \mathrm{K}^{+}$-ATPase [1-3].

Over the years, there have been a variety of periodic reports suggesting that cardiac glycosides may have an anticancer utilization (reviewed in [4-8]). In vitro and ex vivo experiments have revealed that some cardiac glycosides (e.g., digitoxin) induce selective anticancer effects $[4,9,10]$, which may occur at concentrations commonly found in the plasma of patients treated with these drugs [11]. Some cardiac glycosides have also shown potent and selective anticancer effects in mice harboring human malignant cells $[12,13]$; however, these results should be interpreted cautiously, as mouse cells are much more resistant than human cells to the cytotoxic effects of cardiac glycosides, and it is not clear whether such selectivity is due to selective inhibition of tumor cells or to interspecies differences in sensitivity [14]. The cardiac drugs digitoxin and digoxin, the semisynthetic cardiac glycoside UNBS1450, and two extracts from Nerium oleander Apocynaceae have entered clinical trials for the treatment of cancer (see http://clinicaltrials.gov/ and ref. $[6,7,15,16])$. Recently, however, Perne et al. reported results suggesting that cardiac glycoside-induced cytotoxicity was mediated by general protein synthesis inhibition and was not selective for cancer cells, raising concerns about ongoing clinical trials testing cardiac glycosides as anticancer agents [17]. Later, Hallbook et al. observed that some cardiac glycosides, particularly digitoxin, induced ex vivo selective anticancer effects in leukemia cells and found that protein synthesis inhibition by cardiac glycosides at concentrations corresponding to $\mathrm{IC}_{50}$ values did not occur in all types of cancer cells [10]. These data suggest that cardiac glycosides may induce selective anticancer effects only in some types of cancer.

Several mechanisms of action have been proposed to participate in the cytotoxic activity of cardiac glycosides (reviewed in [5-8, 16]). However, it is unclear why cancer cells are generally more susceptible than nonmalignant cells to the cytotoxic activity of these compounds. Recent data have revealed that cancer cells have a higher reliance on glycolysis for their survival than normal cells, and that the inhibition of glycolysis may cause selective anticancer effects $[5,18,19]$. In this communication, we have assessed the selective cytotoxic activity of a hydroalcoholic extract from the leaves of the cardenolide-containing plant Nerium oleander against A549 lung cancer cells vs. MRC5 nonmalignant lung fibroblasts and have evaluated possible mechanisms involved in this activity. Results show that this extract induces selective killing of lung cancer cells and a marked inhibition of glycolysis.

\section{Materials and Methods}

V

Plant material, preparation of the extract, and determination of cardiac glycosides content

The leaves of Nerium oleander L. were collected in June 2010 in Seville (Spain; $37^{\circ} 22^{\prime} 16^{\prime \prime} \mathrm{N}, 5^{\circ} 59^{\prime} 27^{\prime \prime} \mathrm{W}$ ). A voucher specimen (278048) was authenticated by Dr. F. Garcia and is deposited in the herbarium at the Department of Vegetal Biology and Ecology, Faculty of Biology, University of Seville. Fresh leaves of $N$. oleander were extracted with ethanol: water $(1: 1)$ at $60^{\circ} \mathrm{C}$ for 1 hour by using an ultrasound water bath apparatus. Ethanol was eliminated in a rotary vacuum evaporator, and the remaining water solution was lyophilized, with an extraction yield of $2.3 \%$. The cardiac glycoside content of $N$. oleander was determined with the Kedde reaction, a colorimetric technique that allows the determination of unsaturated pentacyclic lactones (present in cardiac glycosides from $N$. oleander) by using 3,5-dinitrobenzoic acid [20]. Briefly, a 3\% solution of 3,5-dinitrobenzoic acid in ethanol was mixed in the ratio $1: 1$ with a solution of $2 \mathrm{M} \mathrm{NaOH}$ in distilled water. $100 \mu \mathrm{L}$ of this mixture was mixed with $150 \mu \mathrm{L}$ of NOE or 2-furanone in ethanol at different concentrations. Optical densities were measured at $540 \mathrm{~nm}$ on a multiwell plate spectrophotometer reader. Based on the standard 2-furanone (lactone of cardenolides), the percentage of cardenolides in the extract was determined, and was expressed as the mean \pm SEM.

\section{Chemicals and cell lines}

Cisplatin (99.9\%), dichloroacetate (98\%), NAC (99\%), 2-furanone (97\%), and catalase were purchased from Sigma. The human A549 lung cancer cell line, the human embryo lung fibroblastic MRC-5 cell line and the human HT29 colon adenocarcinoma cell line were purchased from European Collection of Cell Cultures. The human UACC-62 melanoma cell line was purchased from American Type Culture Collection. The HR-deficient VC8 cell line (V79 Chinese hamster lung cells mutated in BRCA2) and the VC8B2 cell line (VC8 cells complemented with human BRCA2) were kindly provided by Dr. Helleday. All cell lines were maintained in DMEM supplemented with $2 \mathrm{mM}$ glutamine, $50 \mu \mathrm{g} / \mathrm{mL}$ penicillin, $50 \mu \mathrm{g} / \mathrm{mL}$ streptomycin, and $10 \%$ fetal bovine serum, and were cultured at $37^{\circ} \mathrm{C}$ in a humidified atmosphere containing $5 \% \mathrm{CO}_{2}$. Cell culture reagents were obtained from Life Technologies.

\section{Assay for cytotoxic activity}

The MTT assay is a colorimetric technique that allows the quantitative determination of cell viability. It is based on the capability of viable cells to transform the MTT salt (3-(4,5-dimethylthiazol2-yl)-2,5-diphenyltetrazolium bromide) into a formazan dye. Exponentially growing cells were seeded into 96-well plates and drugs were added $24 \mathrm{~h}$ later. Following the incubation period specified in the figures and table legends, the medium was removed, and $125 \mu \mathrm{L}$ MTT ( $1 \mathrm{mg} / \mathrm{mL}$ in medium) was added to each well for 4 hours. Then, $80 \mu \mathrm{L} 20 \%$ SDS in $0.02 \mathrm{M} \mathrm{HCl}$ were added, plates were incubated for 10 hours at $37^{\circ} \mathrm{C}$, and optical densities were measured at $540 \mathrm{~nm}$ on a multiwell plate spectrophotometer reader. Cell viability was expressed as percentage in relation to controls. All data were averaged from at least three independent experiments and were expressed as means \pm SEM.

\section{Immunofluorescence $\boldsymbol{\gamma}$-H2AX focus assay}

The immunofluorescence $\gamma-\mathrm{H} 2 \mathrm{AX}$ focus assay is a sensitive technique to evaluate DNA damage. It is based on the ability of DSBs to trigger phosphorylation of histone H2AX on Ser-139, which leads to the formation of nuclear foci that can be visualized with anti- $\gamma \mathrm{H} 2 \mathrm{AX}$ antibodies [21,22]. Cells were seeded on coverslips and allowed to attach for 24 hours. After treatments, cells were washed three times with PBS, fixed with $4 \%$ paraformaldehyde in PBS for $10 \mathrm{~min}$ at room temperature and washed again three times with PBS. After fixation, cells were permeabilized with $0.5 \%$ Triton X-100 in PBS for 5 minutes and then blocked three times with $0.1 \%$ Tween 20, 1 \% BSA in PBS for 5 minutes each. Cells were then incubated for 30 min with a mouse anti- $\gamma \mathrm{H} 2 \mathrm{AX}$ monoclonal antibody (Upstate, 1:1000 dilution). Cells were washed three times with PBS and blocked three times prior to the incuba- 
tion with a secondary anti-mouse antibody linked to Alexa Fluor 488 (Invitrogen, $1: 1000$ dilution) for $1 \mathrm{~h}$. Cells were washed with PBS, blocked and washed again with PBS as indicated before. DNA was stained with DAPI, and immunofluorescence was observed at 40-fold magnification with an Olympus BX 61 microscope. A total of $\sim 200$ cells/dose were scored, and cells with 20 or more foci were scored as positive. Ionizing radiation was used as a positive control for the assay; cells were exposed to $4 \mathrm{~Gy}$ of ionizing radiation using an X-ray irradiator (Philips MU15F) operated at $100 \mathrm{KV}$ and a dose rate of $1 \mathrm{~Gy} / \mathrm{min}[23]$.

\section{Inhibition of glycolysis}

Glycolysis inhibition was assessed by measuring concentrations of glucose (initial product of glycolysis) and lactate (final product of glycolysis) in control and treated cells. Briefly, $10^{6}$ cells were exposed in 6-well plates to the tested compounds for $8 \mathrm{~h}$, and glucose and lactate concentrations were determined in cell supernatants by using the Accutrend ${ }^{\circledR}$ Plus analyzer together with Accutrend glucose strips and BM-Lactate Strips (Roche Diagnostics). After calibrating the instrument with glucose and lactate calibration strips, test strips were used to determine glucose and lactate levels via colorimetric-oxidase mediator reactions according to the manufacturer's instructions [24]. Results are expressed as percentage of lactate production and percentage of glucose consumption in relation to untreated cells and are shown as means \pm SEM of three independent experiments.

\section{Statistical analysis}

All data were averaged from at least three independent experiments and were expressed as means \pm SEM. For statistical analysis we used the t-test (paired, two-tailed). A p value $>0.05$ is not considered statistically significant and is not represented by any symbol. A p value $<0.05$ is considered to correspond with statistical significance and is indicated with an asterisk $\left(^{*}\right)$, a $\mathrm{p}$ value $<0.01$ is indicated with a double asterisk $\left(^{* *}\right)$, and a $\mathrm{p}$ value $<0.001$ is indicated with a triple asterisk $\left(^{* * *}\right)$.

\section{Results and Discussion}

$\nabla$

Extracts from the leaves of the cardiac glycoside-containing plant Nerium oleander L. have shown anticancer effects in preclinical studies and have entered phase I clinical trials [16, 25, 26]. Because recent data suggest that cardiac glycosides may induce selective anticancer effects only in some types of cancer cells $[10,17]$, the aim of this work was to evaluate whether an extract from this plant induced selective cytotoxic activity in lung cancer cells and to evaluate possible mechanisms involved in this activity. A hydroalcoholic extract from the leaves of $N$. oleander was prepared, and its content in cardiac glycosides (cardenolides) was determined to be $4.75 \pm 0.32 \%$ with the Kedde reaction, which is an accepted methodology for standardizing cardenolides. Another reason for selecting the Kedde reaction for standardizing the extract is that, unlike a chromatographic profile of several of its major constituents, this reaction gives its total cardenolide content. Several extracts from $N$. oleander (but not any of their constituents) have entered clinical trials, therefore suggesting that their anticancer activity is mediated by their total cardenolide content rather than by any particular constituent of the extracts. In addition, it is much easier for any researcher wanting to reproduce our results to use the Kedde reaction than to carry out a chromatographic profile of several constituents of the extract selected by us.
A549 lung cancer cells and MRC5 nonmalignant lung fibroblasts were exposed for $48 \mathrm{~h}$ to several concentrations of this NOE under the same experimental conditions, and cell viability was estimated with the MTT assay. Results, represented in 0 Fig. 1, show that NOE exhibited selective cytotoxicity against the A549 cancer cell line, which was comparable to that of the anticancer drug cisplatin. The $\mathrm{IC}_{50}$ value (means $\pm \mathrm{SEM}$ ) in this cancer cell line was approximately 10 -fold lower for NOE $(0.27 \pm 0.04 \mu \mathrm{g} /$ $\mathrm{mL})$ than for cisplatin $(3.51 \mu \mathrm{g} / \mathrm{mL} ; 11.67 \pm 3.54 \mu \mathrm{M})$. Several compounds were screened against these two cell lines and showed no selective cytotoxicity $[27,28]$. We have also prepared and assessed the cytotoxic activity of an extract of commercial broccoli under the same experimental conditions used for NOE, and we did not observe selective cytotoxicity against the cancer cell line (data not shown). We also evaluated the cytotoxic activity of NOE in the human HT29 colon cancer cell line and in the human UACC62 melanoma cell line and observed that these cancer cells were more resistant than A549 lung cancer cells to the cytotoxicity of NOE; the $\mathrm{IC}_{50}$ values (means $\pm \mathrm{SEM}$ ) were $3.95 \pm 0.37 \mu \mathrm{g} / \mathrm{mL}$ in HT29 cells and $1.73 \pm 0.07 \mu \mathrm{g} / \mathrm{mL}$ in UACC62 cells. Although NOE inhibited the growth of the cancer cell lines HT29 and UACC62 at low concentrations, these concentrations also inhibited the growth of the nonmalignant cell line MRC5 (๑ Fig. 1 B). Overall, these data indicate that NOE inhibits the growth of A549 cancer cells potently and selectively.

Our next goal was to evaluate possible mechanisms involved in the selective cytotoxicity of NOE. We initially evaluated whether the formation of ROS played a role in the cytotoxicity of the extract. Accumulating data suggest that cancer cells have higher basal levels of ROS than nonmalignant cells, and that the induction of a specific increase in ROS levels by pro-oxidant agents may lead to cytotoxic concentrations in cancer cells but not in normal cells. Indeed, oxidative stress has been shown to play an important role in the anticancer activity of several chemotherapeutic agents commonly used in cancer treatment [29-31] and in the cytotoxicity of many natural products [32], including that of the major constituent of $N$. oleander, oleandrin [33]. A549 cells were treated with NOE in the presence and absence of the antioxidants catalase and $\mathrm{N}$-acetylcysteine, and cell viability was estimated with the MTT assay. Both antioxidants slightly but significantly prevented the cytotoxic activity of NOE ( Fig. 2), therefore suggesting that ROS formation participates in the cytotoxicity of NOE but does not play a major role.

DNA-damaging compounds may induce selective cytotoxicity towards tumor cells. These cells commonly have mutations in DNA repair genes which make them vulnerable to the cytotoxic activity of specific DNA-damaging compounds. Unlike tumor cells, normal proliferating cells have an intact DNA damage response that would allow them to repair the DNA damage and therefore to survive treatment with these DNA-damaging compounds [3436]. Because previous reports showed that some cardiac glycosides induce DNA damage [11,37-39], we tested whether NOE induced DNA damage and if such damage participated in the cytotoxicity of the extract. We initially tested the cytotoxicity of NOE in cells with and without BRCA2 (a tumor suppressor gene which plays a critical role in DNA damage repair via the HR repair pathway). The HR-deficient VC8 cell line (V79 Chinese hamster lung cells mutated in BRCA2) and the VC8B2 cell line (VC8 cells complemented with human BRCA2) were exposed for $48 \mathrm{~h}$ to several concentrations of NOE, and cell viability was then estimated with the MTT assay. Results, represented in 0 Fig. $3 \mathrm{~A}$, show that the cytotoxic activity of NOE in cells lacking BRCA2 


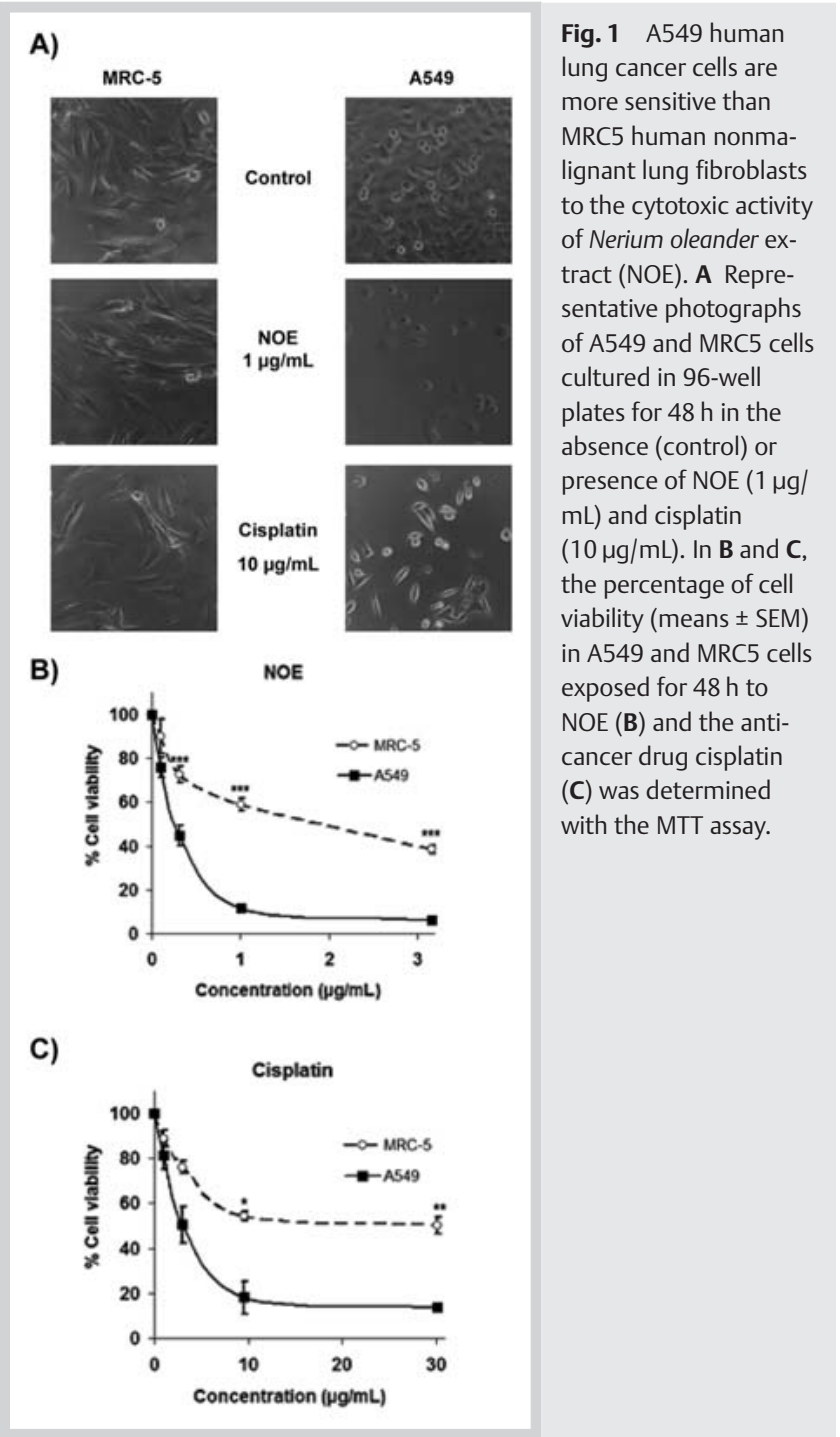

(deficient in HR repair) was slightly but significantly higher than that in parental cells, therefore suggesting that NOE can induce DNA damage and that NOE-induced DNA damage may play a role in its cytotoxicity. It is important to note that the cytotoxicity of NOE in these rodent cells was over 100-fold lower than that in human cells ( Fig. 1), which is highly specific for cardiac glycosides [40]. We next used the immunofluorescence $\gamma$-H2AX focus assay to directly measure the levels of DNA damage induced by NOE in both cell lines and detected moderate levels of DNA damage in cells exposed for $24 \mathrm{~h}$ to NOE $320 \mu \mathrm{g} / \mathrm{mL}$ ( $\odot$ Fig. 3B). As expected, the levels of DNA damage in cells lacking BRCA2 (deficient in HR repair) were somewhat higher than those in parental cells. Taken as a whole, these data suggest that NOE induces DNA damage and that this DNA damage participates in its cytotoxic activity but does not play a major role.

It has been known for some time that glycolysis is coupled to sodium and potassium transport processes and that some cardiac glycosides (e.g., ouabain) can inhibit glycolysis in a variety of nonmalignant cells $[41,42]$. It has recently been found that cancer cells are more reliant on glycolysis for their survival than nonmalignant cells (reviewed in $[18,31]$ ). Based on these findings, we previously proposed that cardiac glycosides might inhibit glycolysis in cancer cells and that such inhibition might play a critical role in the selective cytotoxicity of some cardiac glyco-

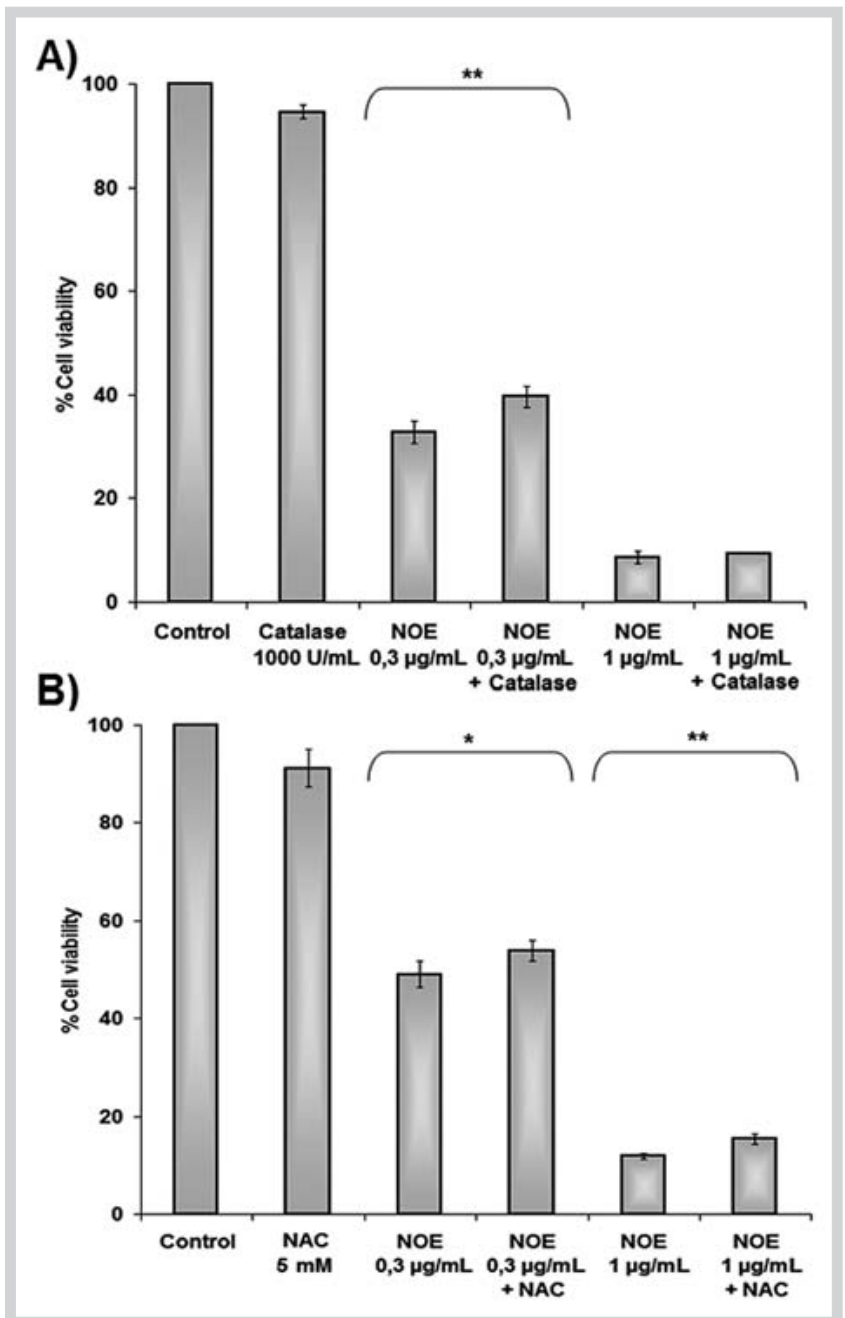

Fig. 2 Catalase and $\mathrm{N}$-acetylcisteine (NAC) slightly prevent the cytotoxic activity of NOE. A549 cells were exposed to NOE for $48 \mathrm{~h}$ in the absence or presence of the antioxidants catalase (A) and NAC (B). The antioxidants were added $0.5 \mathrm{~h}$ before NOE. Cell viability was assessed by the MTT assay.

sides (e.g., digitoxin) towards cancer cells [5]. To test if NOE could inhibit glycolysis, A549 cells were exposed to NOE for $8 \mathrm{~h}$, and glucose and lactate concentrations were determined in cell supernatants. Results, represented in Fig. 4, show that A549 cells exposed to NOE ( 1 and $10 \mu \mathrm{g} / \mathrm{mL}$ ) exhibited a marked reduction in glucose consumption and lactate production, comparable to those observed in cells exposed to the glycolysis inhibitor DCA $32 \mathrm{mM}$. No significant changes in glucose consumption and lactate production were observed in cells exposed to cisplatin $32 \mu \mathrm{M}$. $\odot$ Fig. 4C includes representative photographs of cells exposed for $8 \mathrm{~h}$ to NOE, DCA, and cisplatin, where cell number and morphology can be appreciated. This figure seeks to show that the reduction in glucose consumption and lactate production induced by NOE is not caused by a reduction in cell number (fewer cells would consume less glucose and would produce less lactate). Knowing that glucose and lactate are, respectively, the initial and final products of glycolysis, our data indicate that NOE induces a marked inhibition of glycolysis in A549 lung cancer cells. As mentioned before, cardiac glycosides are known to inhibit the $\mathrm{Na}^{+} / \mathrm{K}^{+}$-ATPase pump. Several mechanisms have been proposed to explain how the inhibition of this pump can lead to glycolysis inhibition [5]. Briefly, inhibition of the $\mathrm{Na}^{+} / \mathrm{K}^{+}$-ATPase pump 


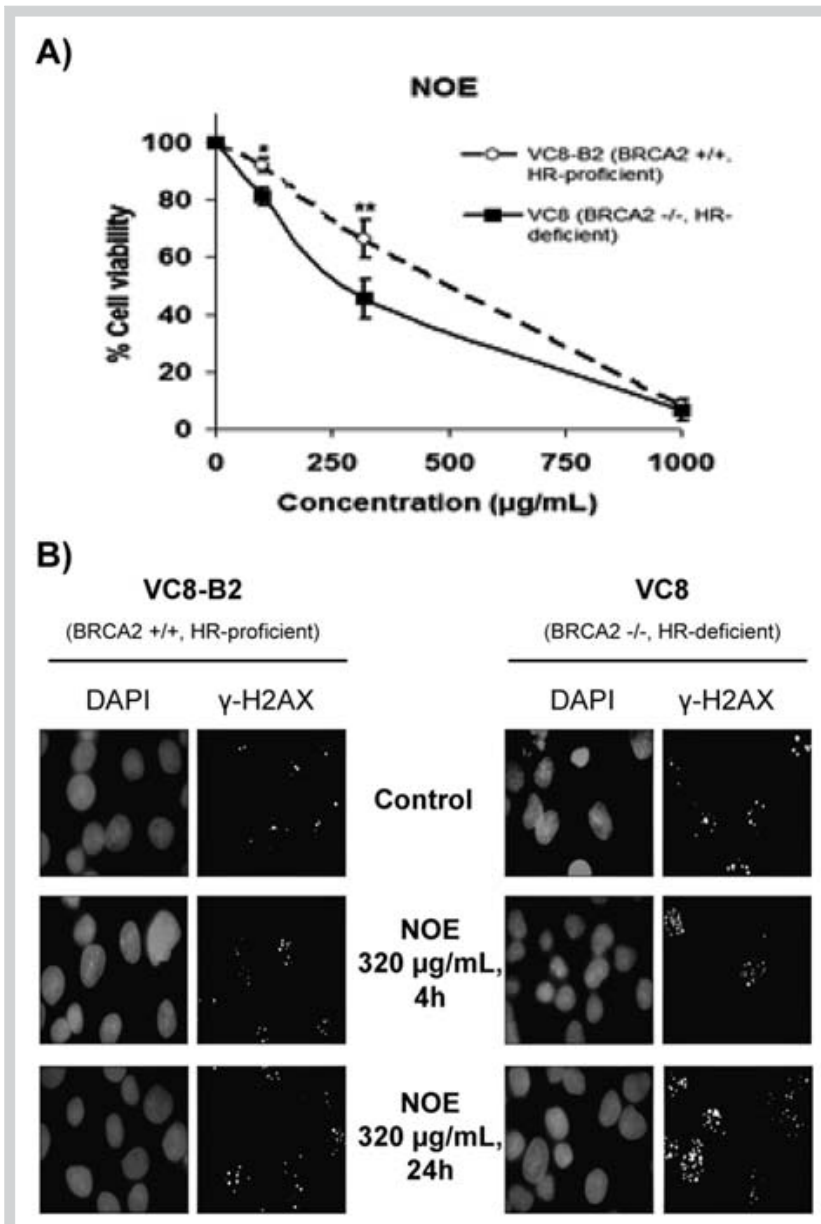

C)

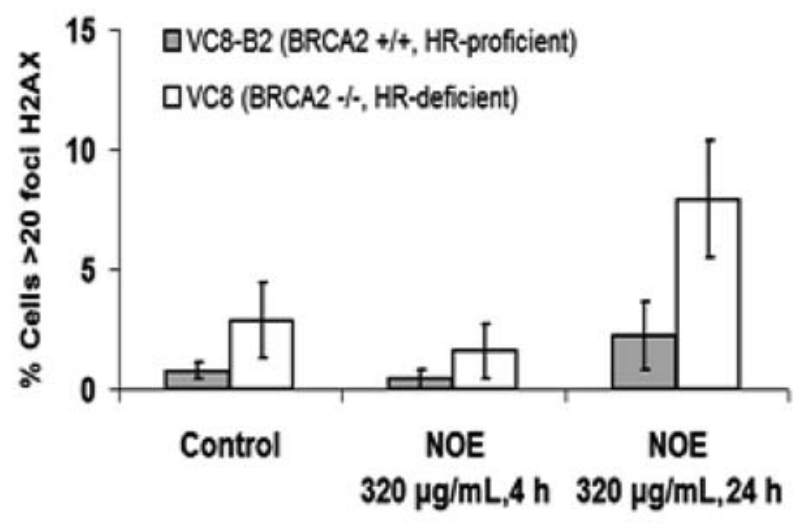

Fig. 3 Induction of DNA damage by NOE and role of homologous recombination (HR) in the repair of NOE-induced DNA damage. (A) VC8 cells (mutated in BRCA2; deficient in HR repair) and VC8-B2 cells (VC8 cells complemented with BRCA2; HR proficient) were exposed to several concentrations of NOE for $48 \mathrm{~h}$, and the percentage of cell viability (means \pm SEM) was determined with the MTT assay. Representative photographs (B) and quantification of nuclear foci (C) in VC8 and VC8-B2 cells exposed for $4 \mathrm{~h}$ and $24 \mathrm{~h}$ to NOE $320 \mu \mathrm{g} / \mathrm{mL}$.

would decrease glycolysis activity by inhibition of the key glycolytic enzyme phosphofructokinase (discussed in reference [5]). In addition, inhibition of the $\mathrm{Na}^{+} / \mathrm{K}^{+}$-ATPase pump may restrict the activity of SGLTs, which couple glucose entry into some types of
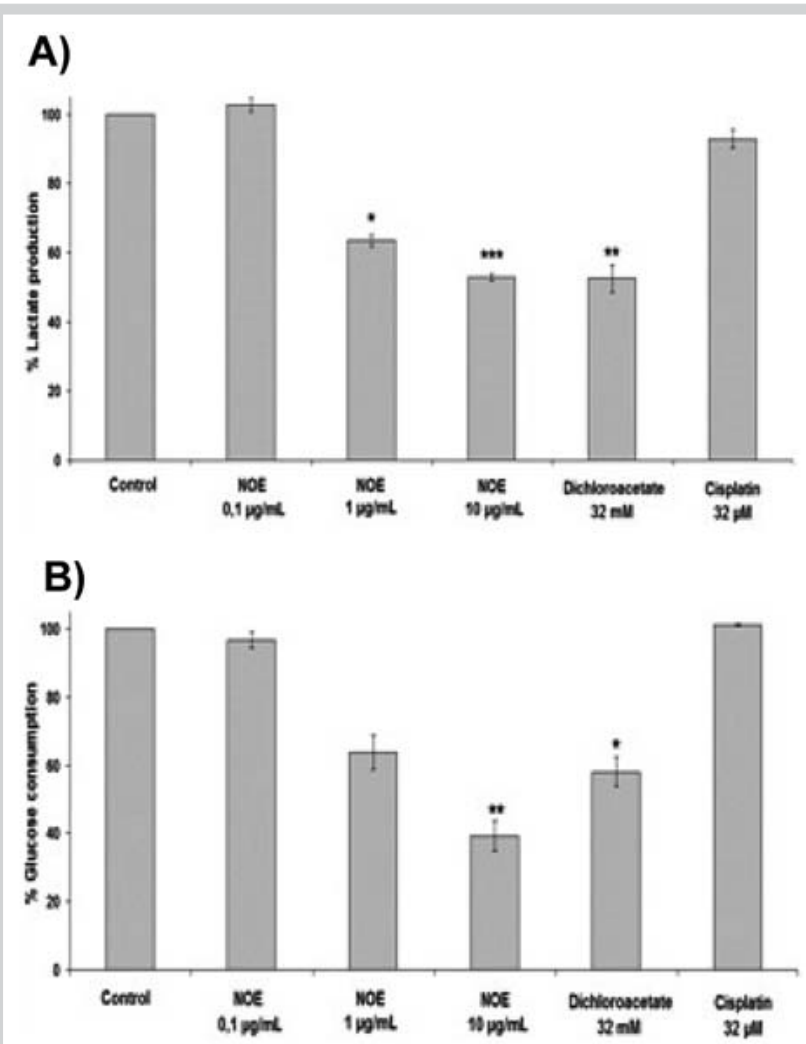

C)
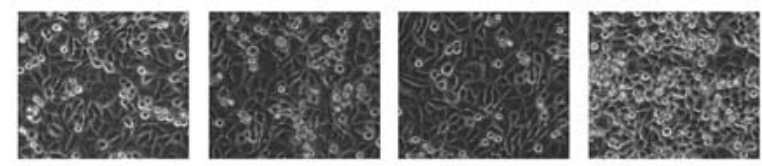

Control

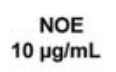

Dichloroacetate
$32 \mathrm{mM}$

Cisplatin
$32 \mu \mathrm{M}$

Fig. 4 NOE induces a marked inhibition of glycolysis in A549 cells. (A) Percentage of lactate production and (B) percentage of glucose consumption in A549 cells exposed for $8 \mathrm{~h}$ to NOE, dichloroacetate (DCA), and cisplatin in relation to untreated cells. (C) Representative photographs of A549 cells exposed for $8 \mathrm{~h}$ to NOE, dichloroacetate, and cisplatin.

cells with the activity of this pump [5]. Although they are typically found in small intestine and renal epithelial cells, clinical data have revealed that these transporters (SGLT2) are overexpressed in lung cancer cells that have metastasized to other organs [43]. This suggests that SGLT2 plays a role in glucose uptake in the metastatic lesions of lung cancer, and that inhibition of the $\mathrm{Na}^{+} / \mathrm{K}^{+}$-ATPase pump by cardiac glycosides may inhibit glycolysis by reducing glucose entry into the cells. The inhibition of glycolysis induced by NOE in A549 lung cancer cells may therefore be caused by inhibition of the $\mathrm{Na}^{+} / \mathrm{K}^{+}$-ATPase pump, which would lead to both the inhibition of the glycolytic enzyme PFK and the inhibition of glucose entry into the cells.

Glycolysis inhibition is well known to produce cytotoxicity. The main cellular roles of glycolysis are to provide building blocks for biosynthesis and ATP, and evidence suggests that inhibition of these processes may have a higher impact on the viability of cancer cells than on that of nonmalignant cells. Indeed, glycolysis inhibition has been proposed to be an anticancer strategy to selectively kill cancer cells [18,31]. Although here we report that NOE induces selective cytotoxicity against lung cancer cells and 
Table 1 Cytotoxic activity of NOE in combination with the anticancer drug cisplatin.

\begin{tabular}{|c|c|c|c|c|c|c|}
\hline \multicolumn{2}{|c|}{ First compound added } & \multicolumn{2}{|c|}{ Second compound added } & \multicolumn{2}{|l|}{ Combination } & \multirow[b]{2}{*}{ Effect } \\
\hline Concentration & \% Cell viability & Concentration & \% Cell viability & $\%$ Cell viability & $\mathrm{Cl}$ & \\
\hline \multirow[t]{3}{*}{$1 \mu \mathrm{M}$ cisplatin } & $85.97 \pm 1.63$ & $32 \mathrm{ng} / \mathrm{mL}$ NOE & $81.30 \pm 2.07$ & $80.11 \pm 2.44$ & 1.40 & -- \\
\hline & & $100 \mathrm{ng} / \mathrm{mL}$ NOE & $65.57 \pm 0.24$ & $58.73 \pm 0.44$ & 1.08 & \pm \\
\hline & & $320 \mathrm{ng} / \mathrm{mL}$ NOE & $28.50 \pm 4.01$ & $24.69 \pm 1.52$ & 0.76 & ++ \\
\hline \multirow[t]{3}{*}{$3 \mu \mathrm{M}$ cisplatin } & $72.59 \pm 2.81$ & $32 \mathrm{ng} / \mathrm{mL}$ NOE & $81.30 \pm 2.07$ & $64.79 \pm 5.82$ & 0.97 & \pm \\
\hline & & $100 \mathrm{ng} / \mathrm{mL} \mathrm{NOE}$ & $65.57 \pm 0.24$ & $50.85 \pm 0.35$ & 0.96 & \pm \\
\hline & & $320 \mathrm{ng} / \mathrm{mL}$ NOE & $28.50 \pm 4.01$ & $22.56 \pm 1.61$ & 0.71 & ++ \\
\hline \multirow{3}{*}{$10 \mu \mathrm{M}$ cisplatin } & $53.82 \pm 0.20$ & $32 \mathrm{ng} / \mathrm{mL} \mathrm{NOE}$ & $81.30 \pm 2.07$ & $49.81 \pm 0.32$ & 1.04 & \pm \\
\hline & & $100 \mathrm{ng} / \mathrm{mL}$ NOE & $65.57 \pm 0.24$ & $37.15 \pm 1.48$ & 0.81 & ++ \\
\hline & & $320 \mathrm{ng} / \mathrm{mL}$ NOE & $28.50 \pm 4.01$ & $21.24 \pm 0.89$ & 0.75 & ++ \\
\hline \multirow[t]{3}{*}{$32 \mu \mathrm{M}$ cisplatin } & $33.00 \pm 2.56$ & $32 \mathrm{ng} / \mathrm{mL}$ NOE & $81.30 \pm 2.07$ & $31.23 \pm 2.21$ & 0.99 & \pm \\
\hline & & $100 \mathrm{ng} / \mathrm{mL}$ NOE & $65.57 \pm 0.24$ & $24.20 \pm 2.84$ & 0.77 & ++ \\
\hline & & $320 \mathrm{ng} / \mathrm{mL}$ NOE & $28.50 \pm 4.01$ & $13.82 \pm 0.52$ & 0.58 & +++ \\
\hline $32 \mathrm{ng} / \mathrm{mL}$ NOE & $90.15 \pm 2.17$ & $1 \mu \mathrm{M}$ cisplatin & $85.97 \pm 1.63$ & $84.91 \pm 3.92$ & 1.20 & - \\
\hline $100 \mathrm{ng} / \mathrm{mL}$ NOE & $72.90 \pm 5.12$ & & & $64.32 \pm 4.00$ & 1.00 & \pm \\
\hline $320 \mathrm{ng} / \mathrm{mL}$ NOE & $24.62 \pm 5.31$ & & & $29.10 \pm 3.90$ & 1.09 & \pm \\
\hline $32 \mathrm{ng} / \mathrm{mL}$ NOE & $90.15 \pm 2.17$ & $3 \mu \mathrm{M}$ cisplatin & $84.65 \pm 3.83$ & $75.65 \pm 1.31$ & 1.18 & - \\
\hline $100 \mathrm{ng} / \mathrm{mL}$ NOE & $72.90 \pm 5.12$ & & & $63.03 \pm 1.93$ & 1.17 & - \\
\hline $320 \mathrm{ng} / \mathrm{mL}$ NOE & $24.62 \pm 5.31$ & & & $34.03 \pm 3.62$ & 1.31 & -- \\
\hline $32 \mathrm{ng} / \mathrm{mL}$ NOE & $90.15 \pm 2.17$ & $10 \mu \mathrm{M}$ cisplatin & $59.78 \pm 2.40$ & $59.33 \pm 3.62$ & 1.09 & \pm \\
\hline $100 \mathrm{ng} / \mathrm{mL}$ NOE & $72.90 \pm 5.12$ & & & $52.39 \pm 3.55$ & 1.19 & - \\
\hline $320 \mathrm{ng} / \mathrm{mL}$ NOE & $24.62 \pm 5.31$ & & & $28.95 \pm 0.12$ & 1.20 & - \\
\hline $32 \mathrm{ng} / \mathrm{mL}$ NOE & $90.15 \pm 2.17$ & $32 \mu \mathrm{M}$ cisplatin & $40.67 \pm 1.93$ & $39.37 \pm 0.93$ & 0.98 & \pm \\
\hline $100 \mathrm{ng} / \mathrm{mL}$ NOE & $72.90 \pm 5.12$ & & & $36.72 \pm 0.55$ & 1.09 & \pm \\
\hline $320 \mathrm{ng} / \mathrm{mL}$ NOE & $24.62 \pm 5.31$ & & & $28.45 \pm 0.90$ & 1.47 & --- \\
\hline
\end{tabular}

A549 cancer cells were exposed for 44-48 h to several concentrations of NOE, cisplatin, and NOE in combination with cisplatin (NOE was added $4 \mathrm{~h}$ before cisplatin or vice versa). Cell viability was assessed by the MTT assay. The parameter combination index ( $\mathrm{Cl}$ ) was calculated with the computer software Compusyn. $\mathrm{A} C \mathrm{Cl}$ value $<0.9$ is considered to be synergism and is represented by "+++++" for very strong synergism $(\mathrm{Cl}<0.1)$, "++++" for strong synergism $(\mathrm{Cl}=0.1-0.3)$, "+++" for synergism $(\mathrm{Cl}=0.3-0.7)$, "++" for moderate synergism $(\mathrm{Cl}=0.7-0.85)$, and "+" for slight synergism $(\mathrm{Cl}=0.85-0.9)$. A Cl value between 0.9 and 1.1 corresponds with the additive effect and is indicated with " \pm ". A Cl value $>1.1$ is considered to be antagonism and is represented by “-” for slight antagonism ( $\mathrm{Cl}=1.1-1.2)$, "-- " for moderate antagonism ( $\mathrm{Cl}=1.2-1.45)$, “-- - for antagonism $(\mathrm{Cl}=1.45-3.3)$, “-- - -" for strong antagonism $(\mathrm{Cl}=3.3-10)$, and “-----" for very strong antagonism $(\mathrm{Cl}>10)$

that this extract induces a marked inhibition of glycolysis, we cannot conclude that NOE-induced inhibition of glycolysis is responsible for its selective anticancer activity. Evidence suggests that the expression and cellular location of $\mathrm{Na}^{+} / \mathrm{K}^{+}$-ATPase alpha subunits in different types of cells (i.e., rodent cells, human cancer cells, and human nonmalignant cells) may explain why different cells are more or less susceptible to the cytotoxic activity of cardiac glycosides [44-46]. The study of the possible association between the expression and cellular location of $\mathrm{Na}^{+} / \mathrm{K}^{+}$-ATPase alpha subunits and the ability of cardiac glycosides to inhibit glycolysis would help reveal whether the inhibition of glycolysis by these compounds plays a role in their selective cytotoxicity.

Since most cancer chemotherapy regimens include a combination of drugs, and since platinum compounds are widely used in the treatment of lung cancer, we assessed the cytotoxic activity of NOE in combination with cisplatin in A549 lung cancer cells. Then, we calculated the parameter CI with the computer software Compusyn; this parameter is based on the Chou-Talalay method and offers a quantitative definition for the additive effect $(\mathrm{CI}=1)$, synergism $(\mathrm{CI}<1)$, and antagonism $(\mathrm{CI}>1)$ in drug combinations [47]. A549 cells were exposed for $44-48 \mathrm{~h}$ to several concentrations of cisplatin, NOE, and cisplatin in combination with NOE. Cell viability was then estimated with the MTT assay. Results, collected in $\bigcirc$ Table 1, revealed a moderate antagonism when NOE was added $4 \mathrm{~h}$ before cisplatin but a moderate synergism when NOE was administered $4 \mathrm{~h}$ after cisplatin. Evidence suggests that the $\mathrm{Na}^{+} / \mathrm{K}^{+}$-ATPase alpha1 subunit plays a role in the intracellular accumulation of cisplatin and that cardiac glycosides can reduce its intracellular accumulation [48]; this may explain the moderate antagonisms observed when cells were treated with NOE before cisplatin ( Table 1). Administration of NOE after cisplatin might induce a moderate synergism by circumventing a variety of resistance pathways discussed elsewhere $[16,49]$.

In conclusion, this work reports that an extract from the leaves of the cardiac glycoside-containing plant Nerium oleander exerts selective cytotoxic activity towards lung cancer cells and induces a marked inhibition of glycolysis that may play a role in this activity. It also shows that NOE-induced DNA damage and ROS formation participate moderately in its cytotoxicity, and that the administration of NOE after the anticancer drug cisplatin may induce synergistic cytotoxicity. Since phase I clinical trials have revealed that extracts from the leaves of Nerium oleander are well tolerated and may induce anticancer effects $[16,25,26]$, the present results support their possible advancement into phase II clinical trials for the treatment of lung cancer.

\section{Conflict of Interest}

The authors declare that they do not have conflicts of interest.

\section{References}

1 Rahimtoola SH, Tak T. The use of digitalis in heart failure. Curr Probl Cardiol 1996; 21: 781-853

2 Xie Z, Askari A. $\mathrm{Na}(+) / \mathrm{K}(+)-A T P a s e$ as a signal transducer. Eur J Biochem 2002; 269: 2434-2439

3 Schoner W, Scheiner-Bobis G. Endogenous and exogenous cardiac glycosides: their roles in hypertension, salt metabolism, and cell growth. Am J Physiol Cell Physiol 2007; 293: C509-C536 
4 Haux J. Digitoxin is a potential anticancer agent for several types of cancer. Med Hypotheses 1999; 53: 543-548

5 Lopez-Lazaro M. Digitoxin as an anticancer agent with selectivity for cancer cells: possible mechanisms involved. Expert Opin Ther Targets 2007; 11: 1043-1053

6 Newman RA, Yang P, Pawlus AD, Block KI. Cardiac glycosides as novel cancer therapeutic agents. Mol Interv 2008; 8: 36-49

7 Prassas I, Diamandis EP. Novel therapeutic applications of cardiac glycosides. Nat Rev Drug Discov 2008; 7: 926-935

8 Mijatovic T, Van Quaquebeke E, Delest B, Debeir O, Darro F, Kiss R. Cardiotonic steroids on the road to anti-cancer therapy. Biochim Biophys Acta 2007; 1776: 32-57

9 Sreenivasan Y, Raghavendra PB, Manna SK. Oleandrin-mediated expression of Fas potentiates apoptosis in tumor cells. J Clin Immunol 2006; 26: 308-322

10 Hallbook H, Felth J, Eriksson A, Fryknas M, Bohlin L, Larsson R, Gullbo J. Ex vivo activity of cardiac glycosides in acute leukaemia. PLoS One 2011; 6: e15718

11 Lopez-Lazaro M, Pastor N, Azrak SS, Ayuso MJ, Austin CA, Cortes F. Digitoxin inhibits the growth of cancer cell lines at concentrations commonly found in cardiac patients. J Nat Prod 2005; 68: 1642-1645

12 Mijatovic T, Op DB, Van Quaquebeke E, Dewelle J, Darro F, de Launoit $Y$, Kiss $R$. The cardenolide UNBS1450 is able to deactivate nuclear factor kappaB-mediated cytoprotective effects in human non-small cell lung cancer cells. Mol Cancer Ther 2006; 5: 391-399

13 Zhang H, Qian DZ, Tan YS, Lee K, Gao P, Ren YR, Rey S, Hammers H, Chang D, Pili R, Dang CV, Liu JO, Semenza GL. Digoxin and other cardiac glycosides inhibit HIF-1alpha synthesis and block tumor growth. Proc Natl Acad Sci USA 2008; 105: 19579-19586

14 Lopez-Lazaro M. Digoxin, HIF-1, and cancer. Proc Natl Acad Sci USA 2009; 106: E26

15 Rashan LJ, Franke K, Khine MM, Kelter G, Fiebig HH, Neumann J, Wessjohann LA. Characterization of the anticancer properties of monoglycosidic cardenolides isolated from Nerium oleander and Streptocaulon tomentosum. J Ethnopharmacol 2011; 134: 781-788

16 Mijatovic T, Kiss R. Cardiotonic steroids-mediated $\mathrm{Na}+/ \mathrm{K}+-$ ATPase targeting could circumvent various chemoresistance pathways. Planta Med 2013; 79: 189-198

17 Perne A, Muellner MK, Steinrueck M, Craig-Mueller N, Mayerhofer J, Schwarzinger I, Sloane M, Uras IZ, Hoermann G, Nijman SM, Mayerhofer $M$. Cardiac glycosides induce cell death in human cells by inhibiting general protein synthesis. PLoS One 2009; 4: e8292

18 Pelicano H, Martin DS, Xu RH, Huang P. Glycolysis inhibition for anticancer treatment. Oncogene 2006; 25: 4633-4646

19 Lopez-Lazaro M. The Warburg effect: why and how do cancer cells activate glycolysis in the presence of oxygen? Anticancer Agents Med Chem 2008; 8: 305-312

20 Lopez-Lazaro M, Palma DLP, Pastor N, Martin-Cordero C, Navarro E, Cortes F, Ayuso MJ, Toro MV. Anti-tumour activity of Digitalis purpurea L. subsp. heywoodii. Planta Med 2003; 69: 701-704

21 Watters GP, Smart DJ, Harvey JS, Austin CA. H2AX phosphorylation as a genotoxicity endpoint. Mutat Res 2009; 679: 50-58

22 Lobrich M, Shibata A, Beucher A, Fisher A, Ensminger M, Goodarzi AA, Barton O, Jeggo PA. gammaH2AX foci analysis for monitoring DNA double-strand break repair: strengths, limitations and optimization. Cell Cycle 2010; 9: 662-669

23 Pastor N, Pinero J, Ortiz T, Mateos JC, De Miguel M, Cortes F. Topoisomerase activities and levels in irradiated Chinese hamster AA8 cells and in its radiosensitive mutant EM9. Int J Radiat Biol 1999; 75: 1035-1042

24 Cao X, Bloomston M, Zhang T, Frankel WL, Jia G, Wang B, Hall NC, Koch $R M$, Cheng H, Knopp MV, Sun D. Synergistic antipancreatic tumor effect by simultaneously targeting hypoxic cancer cells with HSP90 inhibitor and glycolysis inhibitor. Clin Cancer Res 2008; 14: 1831-1839

25 Mekhail T, Kaur H, Ganapathi R, Budd GT, Elson P, Bukowski RM. Phase 1 trial of Anvirzel in patients with refractory solid tumors. Invest New Drugs 2006; 24: 423-427

26 Henary HA, Kurzrock R, Falchook GS, Naing A, Moulder SL, Wheler JJ, Tsimberidou AM, Durand J, Yang P, Johansen MJ, Newman R, Khan R, Patel $U$, Hong DS. Final results of a first-in-human phase I trial of PBI05204, an inhibitor of AKT, FGF-2, NF-Kb, and p70S6K in advanced cancer patients. ASCO Meeting Abstracts 2011; 29: 3023

27 Lopez-Lazaro M, Calderon-Montano JM, Burgos-Moron E, Austin CA. Green tea constituents (-)-epigallocatechin-3-gallate (EGCG) and gallic acid induce topoisomerase I- and topoisomerase II-DNA complexes in cells mediated by pyrogallol-induced hydrogen peroxide. Mutagenesis 2011; 26: 489-498
28 Vega-Perez JM, Palo-Nieto C, Periñan I, Vega-Holm M, Calderon-Montano JM, Lopez-Lazaro M, Iglesias-Guerra F. Stereoselective dihydroxylation reaction of alkenyl $\beta$-D-hexopyranosides: a methodology for the synthesis of glycosylglycerol derivatives and $1-0$-acyl-3-O- $\beta$-D-glycosylsn-glycerol analogues. Eur J Org Chem 2012; 6: 1237-1252

29 Alexandre J, Batteux F, Nicco C, Chereau C, Laurent A, Guillevin L, Weill B, Goldwasser F. Accumulation of hydrogen peroxide is an early and crucial step for paclitaxel-induced cancer cell death both in vitro and in vivo. Int J Cancer 2006; 119: 41-48

30 Lopez-Lazaro M. Dual role of hydrogen peroxide in cancer: Possible relevance to cancer chemoprevention and therapy. Cancer Lett 2007; 252: $1-8$

31 Lopez-Lazaro $M$. A new view of carcinogenesis and an alternative approach to cancer therapy. Mol Med 2010; 16: 144-153

32 Martin-Cordero C, Leon-Gonzalez AJ, Calderon-Montano JM, Burgos-Moron E, Lopez-Lazaro $M$. Pro-oxidant natural products as anticancer agents. Curr Drug Targets 2012; 13: 1006-1028

33 Newman RA, Yang P, Hittelman WN, Lu T, Ho DH, Ni D, Chan D, Vijjeswarapu M, Cartwright C, Dixon S, Felix E, Addington C. Oleandrin-mediated oxidative stress in human melanoma cells. J Exp Ther Oncol 2006; 5: $167-181$

34 Helleday T, Petermann E, Lundin C, Hodgson B, Sharma RA. DNA repair pathways as targets for cancer therapy. Nat Rev Cancer 2008; 8: $193-$ 204

35 Lord CJ, Ashworth A. The DNA damage response and cancer therapy. Nature 2012; 481: 287-294

36 Postel-Vinay S, Vanhecke E, Olaussen KA, Lord CJ, Ashworth A, Soria JC. The potential of exploiting DNA-repair defects for optimizing lung cancer treatment. Nat Rev Clin Oncol 2012; 9: 144-155

37 Bielawski K, Winnicka K, Bielawska A. Inhibition of DNA topoisomerases I and II, and growth inhibition of breast cancer MCF-7 cells by ouabain, digoxin and proscillaridin A. Biol Pharm Bull 2006; 29: 1493-1497

38 Jornada LK, Valvassori SS, Arent CO, Leffa D, Damiani AA, Hainzenreder $G$, Ferreira CL, Moretti M, Andrade VM, Quevedo J. DNA damage after intracerebroventricular injection of ouabain in rats. Neurosci Lett 2010; 471: 6-9

39 Hiyoshi H, Abdelhady S, Segerstrom L, Sveinbjornsson B, Nuriya M, Lundgren TK, Desfrere L, Miyakawa A, Yasui M, Kogner P, Johnsen JI, Andang $M$, Uhlen $P$. Quiescence and gammaH2AX in neuroblastoma are regulated by ouabain/Na,K-ATPase. Br J Cancer 2012; 106: 1807-1815

40 Gupta RS, Chopra A, Stetsko DK. Cellular basis for the species differences in sensitivity to cardiac glycosides (digitalis). J Cell Physiol 1986; 127 197-206

41 Paul RJ, Bauer M, Pease W. Vascular smooth muscle: aerobic glycolysis linked to sodium and potassium transport processes. Science 1979; 206: $1414-1416$

42 James JH, Fang CH, Schrantz SJ, Hasselgren PO, Paul RJ, Fischer JE. Linkage of aerobic glycolysis to sodium-potassium transport in rat skeletal muscle. Implications for increased muscle lactate production in sepsis. J Clin Invest 1996; 98: 2388-2397

43 Ishikawa N, Oguri T, Isobe T, Fujitaka K, Kohno N. SGLT gene expression in primary lung cancers and their metastatic lesions. Jpn J Cancer Res 2001; 92: 874-879

44 Yang P, Menter DG, Cartwright C, Chan D, Dixon S, Suraokar M, Mendoza $G$, Llansa N, Newman RA. Oleandrin-mediated inhibition of human tumor cell proliferation: importance of Na,K-ATPase alpha subunits as drug targets. Mol Cancer Ther 2009; 8: 2319-2328

45 Mijatovic T, Roland I, Van Quaquebeke E, Nilsson B, Mathieu A, Van Vynckt F, Darro F, Blanco G, Facchini V, Kiss R. The alpha1 subunit of the sodium pump could represent a novel target to combat non-small cell lung cancers. J Pathol 2007; 212: 170-179

46 Yang P, Cartwright C, Efuet E, Hamilton SR, Wistuba II, Menter D, Addington C, Shureiqi I, Newman RA. Cellular location and expression of $\mathrm{Na}(+)$, $\mathrm{K}(+)$-ATPase alpha subunits affect the anti-proliferative activity of oleandrin. Mol Carcinogen, advance online publication 16 Oct 2012; DOI: $10.1002 / \mathrm{mc} .21968$

47 Chou TC. Drug combination studies and their synergy quantification using the Chou-Talalay method. Cancer Res 2010; 70: 440-446

48 Kishimoto S, Kawazoe Y, Ikeno M, Saitoh M, Nakano Y, Nishi Y, Fukushima S, Takeuchi Y. Role of Na+, K+-ATPase alpha1 subunit in the intracellular accumulation of cisplatin. Cancer Chemother Pharmacol 2006; 57: 84-90

49 Mijatovic T, Dufrasne F, Kiss R. Cardiotonic steroids-mediated targeting of the $\mathrm{Na}(+) / \mathrm{K}(+)$-ATPase to combat chemoresistant cancers. Curr Med Chem 2012; 19: 627-646 